\title{
Illicit GM cotton sparks corporate fury
}

\section{K. S. Jayaraman, New Delhi}

Ten thousand hectares of unauthorized transgenic cotton have been found in India. The news has angered firms waiting to grow genetically modified (GM) crops in the country, and raises serious questions about the ability of developing nations to regulate the introduction of GM varieties.

The discovery - made by researchers from a company seeking to win legal authorization for the cultivation of a crop carrying the same gene - comes hard on the heels of the revelation that transgenic corn is growing in the wild in Mexico (see Nature 413,337; 2001).

Scientists at the Mumbai-based Maha-

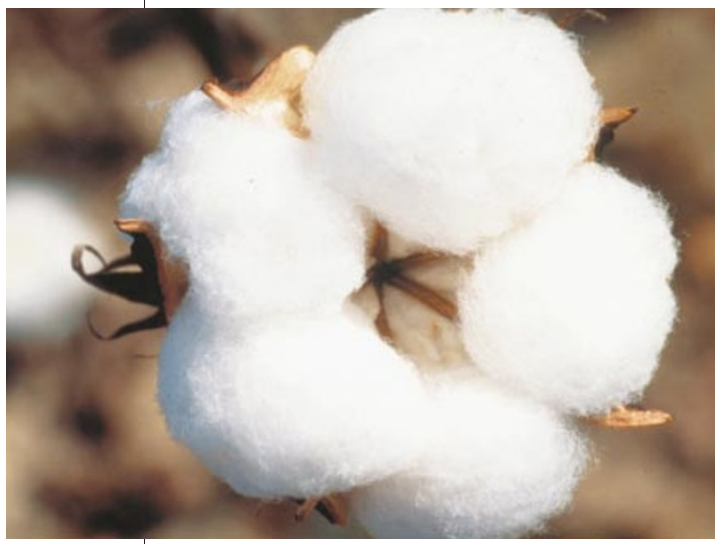

Budding problem: thousands of hectares of transgenic cotton have been found in India. rashtra Hybrid Seeds Company (Mahyco), in which US transgenic-crop giant Monsanto holds a $26 \%$ stake, discovered the cotton on farms in the western state of Gujarat, and informed the regulatory authorities. Monsanto holds a patent on the transgene involved, from the bacterium Bacillus thuringiensis $(B t)$. This encodes an insecticidal protein that allows the cotton to resist bollworm pests. Mahyco has been conducting field trials of the crop in India with a view to obtaining permission for its commercial use as early as next year.

The farmers in Gujarat had purchased the transgenic seeds from Navbharat, a company based in the state capital, Ahmedabad. Navbharat is thought to have developed the seed as a hybrid from transgenic seed imported from the United States.

The Genetic Engineering Approval Committee (GEAC) - a branch of the Indian Ministry of Environment and Forests, whose permission is required for any largescale use of genetically modified organisms - has demanded an explanation from the company of how it came to be selling the seed without permission.

The discovery that the bollwormresistant seeds are already available in Gujarat has infuriated Mahyco, which has spent US\$8 million on preparing to commercialize $B t$ cotton in India. Mahyco's managing director, Raju Barwale, says his company wants "strong and immediate action" against Navbharat for its "blatant contravention of the legal and regulatory processes".

D. B. Desai, managing director of Navbharat, says his company will reserve comment on the allegations until he meets with GEAC officials. He declines to say where the seeds came from, although sources close to the company say they were brought from the United States (where Monsanto's GM seeds are freely available for sale) two-and-a-half years ago, and crossed with an Indian cotton variety to produce the hybrid. The sources add that Navbharat is likely to argue that it uses seeds from many sources, and lacks the technology to detect the transgenic strain in seed imported from the United States.

E. A. Siddiq, chairman of an Indian Department of Biotechnology committee that monitors transgenic crops, says: "This is a foretaste of a frightening situation where transgenics will be out of control and all over the place."

Arvind Kapur, vice-president of the All India Biotech Association, says that lawabiding biotechnology companies will suffer unless the government establishes tighter control of the sale of transgenic seeds.

To address the problem, argues P. K. Ghosh, a senior official at the biotechnology department, India needs to spend Rs100 million (US\$2 million) on six national laboratories equipped to monitor genetically modified organisms more closely.

\section{US lays out bare bones of fossil protection package}

Rex Dalton, Bozeman, Montana

A proposed package of new federal laws to protect palaeontological specimens on federal land and improve the management of palaeontology resources across the United States was announced last week.

The Paleontological Resources Preservation Act was introduced in the House of Representatives on 2 October. It has already been backed by the Society of Vertebrate Paleontology (SVP), which held its annual meeting in Bozeman, Montana, last week, and several federal agencies.

The act would increase the criminal penalties for stealing palaeontological specimens from federal land, unify federal policies for protecting and managing palaeontological resources, and better coordinate the recording of palaeontological discoveries.

"This bill will ensure that fossils will not be removed from the public domain, but are preserved for the enjoyment and education of all Americans for all time," says Richard
Stucky, president of the SVP and head of palaeontology at the Museum of Nature and Science in Denver, Colorado.

There are already laws against the unauthorized removal of palaeontological specimens. But the act would create a more uniform statute and raise the profile of protection efforts. It also requires that specimens are collected by qualified researchers with appropriate permits, who will then deposit the specimens in public institutions.

The act is modelled on the Archeological Resources Protection Act, enacted in 1979 to control looting and improve studies of Native American sites.

The new act was introduced by Representative James McGovern (Democrat, Massachusetts) and five other members, both Democrat and Republican. "I strongly believe we need a more comprehensive and thoughtful approach towards managing these public resources - an approach based on science not profit," says McGovern.
Palaeontologists hope the act will control the black market in looted palaeontological specimens. The illicit international fossil market was highlighted by a recent case in which dealers are charged with stealing a near-complete Allosaurus skeleton a decade ago from federal land in Utah.

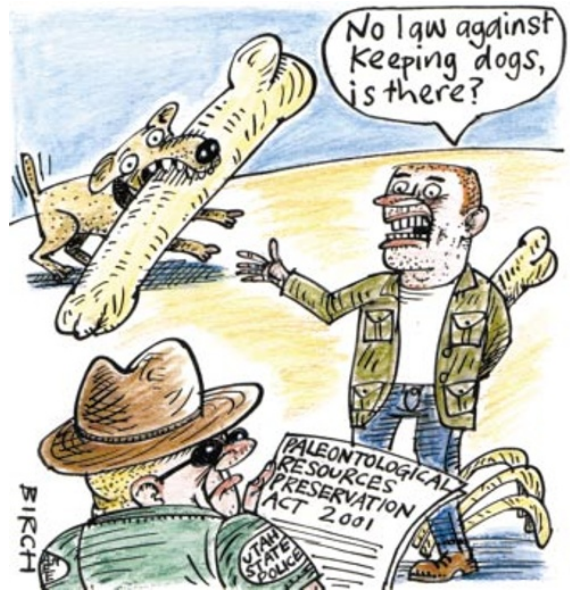

